\title{
Peptide ligation by chemoselective aminonitrile coupling in water
}

Pierre Canavelli ${ }^{1}$, Saidul Islam ${ }^{1}$ and Matthew W. Powner ${ }^{1 *}$

1. Department of Chemistry, University College London, 20 Gordon Street, London, WC1H 0AJ, UK

Amide bond formation is one of the most important reactions in both chemistry and biology ${ }^{1-4}$, but there is currently no chemical method to achieve $\alpha$-peptide ligation in water that tolerates all twenty proteinogenic amino acids at the peptide ligation site. The universal genetic code establishes the biological role of peptides predates Life's last universal common ancestor and that peptides played an essential role in the origins of Life ${ }^{5-9}$. The essential role of sulfur in the citric acid cycle, non-ribosomal peptide synthesis and polyketide biosynthesis points towards thioester-dependent peptide ligations preceding RNA-dependent protein synthesis during the evolution of Life ${ }^{5,9-13}$. However, a robust mechanism for aminoacyl thioester formation has never been demonstrated ${ }^{13}$. Here, we report a chemoselective, high yielding $\alpha$-aminonitrile ligation that exploits only prebiotically plausible molecules—hydrogen sulfide, thioacetate ${ }^{12,14}$ and ferricyanide $\mathrm{e}^{12,14-17}$ or cyanoacetylene $\mathrm{o}^{8,14}$ — to yield $\alpha$ peptides in water. The ligation is extremely selective for $\alpha$-aminonitrile coupling and tolerates all 20 proteinogenic amino acid residues. Two essential features enable the peptide ligation in water: 1) the reactivity and $\mathrm{p} K_{\mathrm{aH}}$ of $\alpha$-aminonitriles makes them compatible with ligation at neutral $\mathrm{pH}$, and 2) $\mathrm{N}$ acylation stabilises the peptide product and activates the peptide precursor to (biomimetic) $N \rightarrow C$ peptide ligation. Our model unites prebiotic aminonitrile synthesis and biological $\alpha$-peptides, suggesting short $N$-acyl peptide nitriles were plausible substrates during early evolution.

To improve the efficiency and selectivity of peptide ligation in water we sought to develop a novel mechanism for non-enzymatic peptide synthesis, which would operate via biomimetic $\mathrm{N} \rightarrow \mathrm{C}$ ligation in near-neutral $\mathrm{pH}$ water, and we suspected that a combination of sulfur and nitrile chemistry would be required (Fig. 1a) $)^{8,9,14,18-}$ 21. Proteinogenic $\alpha$-aminonitriles (AA-CN) are readily synthesised ${ }^{8,18}$, and their direct ligation would provide the simplest prebiotic pathway to peptides. Unfortunately, incubation of AA-CN in water results in extremely ineffective peptide synthesis ${ }^{22}$. $\alpha$-Amino acids (AA) are widely assumed to be prebiotic precursors of peptides, but the harsh conditions (typically strongly acidic or alkaline solutions) required for AA formation from AA$\mathrm{CN}$ are incompatible with the integrity of both peptides and electrophilic activating agents. Therefore, we sought a more congruent and direct pathway from $\alpha$-aminonitriles to $\alpha$-peptides, and although the conversion of AA-CN to AA-SH has never been reported ${ }^{23}$, harnessing the AA-CN nitrile moiety for thioacid synthesis seemed more prudent than dissipating its activation through exhaustive hydrolysis. 
Orgel has previously suggested that $\alpha$-aminothioacids (AA-SH) ${ }^{16}$ might offer an interesting alternative to biological thioesters ${ }^{10,11}$. AA-SH unite excellent aqueous stability with highly selective (electrophilic or oxidative) activation ${ }^{12,14,16,24}$, but their prebiotic synthesis presents difficulties ${ }^{25}$ and they undergo inefficient ligation at near-neutral $\mathrm{pH}$ (Supplementary Discussion) $)^{16,26}$. To overcome these problems we reconsidered the synthesis of thioacids from nitriles (Fig. 1b). Recently we reported high yielding nucleophilic displacement of sulfides by Gly-CN ${ }^{19}$ is promoted by the low $\mathrm{p} K_{\mathrm{aH}}$ of $\alpha$-aminonitriles in water, and we hypothesised that coupling AA-CN to the $C$-terminus of a growing peptide would be facile at neutral $\mathrm{pH}$. Importantly, we suspected this ligation would (electronically) activate the nitrile moiety to thiolysis. Accordingly, $\alpha$ aminonitrile $N$-acylation, which appears essential to prevent diketopiperazine (DKP) induced peptide degradation ${ }^{27,28}$ (Fig. 1c), would initiate peptide synthesis by promoting thioacid synthesis.

Ferricyanide-mediated acetylation of AA-CN (50 mM) by AcSH (3 equiv.) ${ }^{12,14}$ gave $\alpha$-amidonitriles (Ac-AA$\mathrm{CN}$ ) in near-quantitative yield in water (Table 1). As anticipated, acylation of AA-CN activated the nitrile moiety, and quantitative conversion of Ac-AA-CN to Ac-AA-SNH 2 was observed upon incubation with $\mathrm{H}_{2} \mathrm{~S}$ (10 equiv., pH 9, room temperature, 1-4 d) (Supplementary Fig. 39-52, 64, 80). Incubation of Ac-Gly-CN $(50 \mathrm{mM})$ and Gly-CN $(50 \mathrm{mM})$ or acetonitrile $(50 \mathrm{mM})$ with $\mathrm{H}_{2} \mathrm{~S}(0.25 \mathrm{M}, \mathrm{pH}$, room temperature, $24 \mathrm{~h})$ gave smooth conversion to Ac-Gly-SNH 2 (91\%), whereas only 7\% of Gly-CN was converted to Gly-SNH (Supplementary Fig. 18) and acetonitrile thiolysis was not observed (Supplementary Fig. 20). This demonstrates the pronounced nitrile activation provided by acylation. Electrophilic activation is also specific to $\alpha$-amidonitriles; for example, the reaction of Ac-Gly-CN and Ac- $\beta$-Ala-CN (1:1) with $\mathrm{H}_{2} \mathrm{~S}$ results in almost exclusive $\alpha$-amidonitrile thiolysis (Fig. 1e).

Notably, we observed hydrolysis of Ac-AA-SNH 2 to Ac-AA-SH to realise an effective synthesis of thioacids (Fig. 1b). This is in stark contrast to the reactivity of AA-SNH 2 , for which hydrolysis to their respective AA$\mathrm{SH}$ was not observed (Supplementary Discussion and Supplementary Fig. 16). Hydrolysis of Ac-AA-SNH 2 generally furnished the respective Ac-AA-SH in good yields (51-85\%; Table 1 \& Supplementary Fig. 53-58, $64,80)$. However, the sterically bulkier Val residue sluggishly hydrolysed to give the corresponding $\alpha$ amidothioacid Ac-Val-SH in poor yield (8\%; Table 1, entry 9; Supplementary Fig. 59). This amino acid residue is one of several that are notoriously problematic $C$-terminal ligation residues during the (semi)synthesis of peptides in the related process of thioester-mediated Native Chemical Ligation ${ }^{4,29,30}$. Future investigation of catalytic $\alpha$-amidothioacid Ac-AA-SH synthesis is warranted, however we note that (uncatalysed) Ac-Val-CN thiolysis already delivers a seven-fold greater yield of Ac-Val-SH relative to AA- 
SH analogues synthesised by electrophilic AA activation ${ }^{25}$. Furthermore, Ac-AA-SH are highly stable to the condition of their formation, whereas AA-SH are destroyed by the activating agents required for their synthesis ${ }^{25}$.

We next investigated the ligation of Ac-AA-SH. We observed that incubation of Ac-Gly-SH (50 mM) with Gly-CN (2 equiv.) and ferricyanide (3 equiv.) gave Ac-Gly $2-\mathrm{CN}$ in near-quantitative yield over a broad $\mathrm{pH}$ range ( $\mathrm{pH} 5-9$, room temperature). A range of activating agents, including ferricyanide ${ }^{12,14-17}$, cupric salts ${ }^{8}$, cyanoacetylene $^{8,14}$ and $N$-cyanoimidazole ${ }^{14}$ were all found to be effective (Extended Data Table 1), showing that multiple methods of Ac-AA-SH activation towards AA-CN ligation in water are possible.

We then carried out an iterative one-pot AA-CN coupling without isolating the intermediate ligation products. $\alpha$-Amidonitrile Ac-Gly-CN was successively homologated to afford the corresponding peptides Ac-Gly ${ }_{n}-\mathrm{CN}$ $[n=2-5 ; n=2,71 \% ; n=3,71 \% ; n=4,63 \% ; n=5,41 \%$ (Table 2)]. After four iterations of the homologation cycle partial precipitation of Ac-Gly 4 - $\mathrm{CN}$ reduced the overall coupling yield for Ac-Gly ${ }_{5}-\mathrm{CN}$ synthesis (13\% overall yield of Ac-Glys-CN from Ac-Gly-CN; Supplementary Fig. 209-211). This demonstrates that iterative ligation of $\alpha$-aminonitriles AA-CN can be achieved in good yield in water without purification, within the limits of peptide solubility. Our ligation is highly robust and tolerates monomer-by-monomer peptide growth and fragment ligations to produce oligomers in high yield, even at low concentrations (3.1 mM, Table 2, entry 17) and with stoichiometric (1:1) coupling partners (Table 2, entries 5-17). To our knowledge, these are the first examples of fragment ligations with prebiotic substrates in water.

Activation of the $C$-terminus of peptides and amino acids (such as Ac-Ala-OH) with electrophilic reagents (such as 1-ethyl-3-(3-dimethylaminopropyl)carbodiimide, EDC) can result in racemisation ${ }^{31}$. However, we observed the formation of chiral $\alpha$-amidothioacid L-Ac-Ala-SH (from L-Ac-Ala-CN) and its subsequent ligation with Gly-CN proceeds with retention of stereochemistry (Supplementary Fig. 292-294) demonstrating enantiomeric enrichment is preserved during our peptide ligation, which is a testament to the mild ligation conditions.

We next investigated the chemoselectivity and robustness of AA-CN ligation. Stoichiometric (1:1) competition reactions between Gly-CN $(50 \mathrm{mM})$ and ammonia, glycine (Gly), glycine amide $\left(\mathrm{Gly}-\mathrm{NH}_{2}\right), \beta-$ alanine ( $\beta$-Ala), $\beta$-alanine nitrile ( $\beta$-Ala-CN), phosphate, propylamine, cytosine, cytidine-5'-phosphate and adenosine-5'-phosphate across a broad $\mathrm{pH}$ range (pH 5-9; Extended Data Table 2) were investigated. All competition reactions demonstrated outstanding selectivity for Gly-CN ligation ( $>80 \%$ yield) at neutral $\mathrm{pH}$ (Supplementary Fig. 235-244). We observed selective Gly-CN ligation in the presence of Gly-NH $2\left(\mathrm{p} K_{\mathrm{aH}}=\right.$ 
8.4) and $\beta$-Ala-CN $\left(\mathrm{p} K_{\mathrm{aH}}=8.0\right)$ in neutral and acidic solution, but selectivity was lost at $\mathrm{pH}$ values above their $\mathrm{p} K_{\mathrm{aH}}$. The excellent selectivity for AA-CN ligation in neutral solution was attributed to their uniquely suppressed $\mathrm{p} K_{\mathrm{aH}}$ values (e.g. Gly-CN $\left.\mathrm{p} K_{\mathrm{aH}}=5.3\right)^{19}$, which renders them predominantly neutral, and consequently nucleophilic, even in weakly acidic solutions. AA-CN ligation is also observed across a broad temperature range $\left(\mathrm{T}=3-60^{\circ} \mathrm{C}\right)$, as well as at physiologically relevant concentrations $(0.5 \mathrm{mM})($ Extended Data Table 3).

Developing a universal strategy to activate and ligate peptides that accommodates all proteinogenic amino acids is problematic. Lysine and cysteine, for example, contain highly nucleophilic moieties that are incompatible with electrophilic activation ${ }^{2,17,32}$, and aspartate and glutamate have $\beta$ - and $\gamma$-carboxylate residues, respectively, in addition to the $\alpha$-carboxylate that must be selectively activated and ligated ${ }^{2,4,30}$. $\alpha$ Amidothioacid ligation is highly general and chemoselective. All investigated amino acids and their derivatives were coupled in good-to-excellent yields (Tables 1-3, Extended Data Table 4 \& Extended Data Table 5). Sterically congested and $\beta$-branched thioacid ligations were also highly effective; ligations yielding Ac-Phe-Phe-CN, Ac-Phe-Val-CN and Ac-Val-Val-CN were all rapid and high yielding (Extended Data Table 5, entries 18-20). We observed unprecedented protecting-group-free ligation for all 20 proteinogenic sidechain residues, including His, Asp, Lys, Cys, Ser, Thr and Tyr, which are all essential to enzyme catalysis, yet notoriously difficult to ligate under previously reported (prebiotic) conditions ${ }^{2,4,30,32}$. Cys is incompatible with electrophilic activating agents ${ }^{2,32}$, yet it underwent highly selective ligation under our conditions to furnish Ac-Gly-Cys-OH (80\%; Table 3, entry 6) after thiol exchange (Extended Data Fig. 1a).

Following the excellent selectivity of $\alpha$-aminonitrile AA-CN ligation, we challenged the $\alpha-\mathrm{NH}_{2}$ selectivity with lysine, which possesses two amine nucleophiles. We observed poor selectivity for $\alpha$-coupling of Lys $(1.2: 1 \alpha / \varepsilon)$ and Lys-NH $2(2.7: 1 \alpha / \varepsilon)$, but Lys-CN ligated with exceptional $\alpha$-selectivity $(>80: 1 \alpha / \varepsilon ;$ Extended Data Fig. 1b; Supplementary Fig. 149). We then turned our attention to the coupling of AA-CN to a $C$-terminal lysine residue, which requires intermolecular AA-CN coupling to outcompete cyclisation (Extended Data Fig. 1c). We first demonstrated that activation of Ac- $\alpha$-Lys-SH $(30 \mathrm{mM})$ by ferricyanide $(90 \mathrm{mM})$ at $\mathrm{pH} 9.0$ led to rapid lactamisation (92\%). This was not surprising given the close proximity of the $\varepsilon-\mathrm{NH}_{2}$ and thioacid moieties of Ac- $\alpha$-Lys-SH. However, we found that Gly-CN (64 mM) successfully coupled with Ac- $\alpha$-LysSH (32 mM). The intermolecular coupling of Gly-CN outcompeted lactamisation across a broad pH range to give Ac- $\alpha$-Lys-Gly-CN (88-95\%, pH 6.5-9.0, Supplementary Fig. 70-71). The chemoselective coupling of lysine residues at $C$ - and $N$-termini of peptides underscores that $\alpha$-aminonitrile ligation is predisposed to yield $\alpha$-peptides. To the best of our knowledge, these reactions constitute the first non-enzymatic, chemoselective, 
and protecting-group-free intermolecular lysine ligations for native peptide bond formation at near-neutral $\mathrm{pH}^{26,33}$.

In a clear departure from the convention that $\alpha$-amino acids (AA) are essential for prebiotic peptide synthesis, we have found that their precursors, $\alpha$-aminonitriles (AA-CN), are predisposed to undergo selective ligation at biochemically relevant $\mathrm{pH}$ and concentration. $\mathrm{N}$-Acylation initiates our peptide synthesis strategy and activates a ligated aminonitrile to thiolysis and hydrolysis to its respective $\alpha$-amidothioacid. $N$-Acylation circumvents the irreversible derivatisation of peptides by electrophiles (such as $\operatorname{COS}^{17}$, see Supplementary Discussion) and promotes (biomimetic) $\mathrm{N} \rightarrow$ C peptide ligation. Our peptide ligation strategy requires separate sequential delivery of $\mathrm{H}_{2} \mathrm{~S}$ and an activating agent. For example, $\mathrm{H}_{2} \mathrm{~S}$ and ferricyanide are mutually reactive feedstock molecules and would need to be delivered from separate source locations. However, repeated sequential delivery of $\mathrm{H}_{2} \mathrm{~S}$ and then $\alpha$-aminonitriles and an oxidant (e.g. ferricyanide), chalcophilic metal ion (e.g. $\left.\mathrm{Cu}^{2+}\right)$ or an electrophile (e.g. cyanoacetylene) would yield controlled stepwise peptide ligation. Controlled synthesis, which responds to environmental or internal stimuli, is an essential element of metabolic regulation, and we speculate that coupling iterative aminonitrile ligation to metabolic (redox) cycles may lead to positive cooperative feedback during the early evolution of Life.

\section{References}

1 Constable, D. J. C. et al. Key green chemistry research areas-a perspective from pharmaceutical manufacturers. Green Chem. 9, 411-420, (2007).

2 Isidro-Llobet, A., Álvarez, M. \& Albericio, F. Amino acid-protecting groups. Chem. Rev. 109, 24552504, (2009).

3 Pattabiraman, V. R. \& Bode, J. W. Rethinking amide bond synthesis. Nature 480, 471-479 (2011).

4 Kulkarni, S. S., Sayers, J., Premdjee, B. \& Payne, R. J. Rapid and efficient protein synthesis through expansion of the native chemical ligation concept. Nat. Rev. Chem. 2, 0122 (2018).

5 Lee, D. H., Granja, J. R., Martinez, J. A., Severin, K. \& Ghadiri, M. R. A self-replicating peptide. Nature 382, 525-528 (1996).

6 Weber, A. L. \& Pizzarello, S. The peptide-catalyzed stereospecific synthesis of tetroses: A possible model for prebiotic molecular evolution. Proc. Natl. Acad. Sci. U. S. A. 103, 12713-12717 (2006).

7 Adamala, K. \& Szostak, J. W. Competition between model protocells driven by an encapsulated catalyst. Nat. Chem. 5, 495-501 (2013). 
8 Patel, B. H., Percivalle, C., Ritson, D. J., Duffy, C. D. \& Sutherland, J. D. Common origins of RNA, protein and lipid precursors in a cyanosulfidic protometabolism. Nat. Chem. 7, 301-307 (2015).

9 Semenov, S. N. et al. Autocatalytic, bistable, oscillatory networks of biologically relevant organic reactions. Nature 537, 656-660 (2016).

10 Lipmann, F. Attempts to map a process evolution of peptide biosynthesis. Science 173, 875-884 (1971).

11 De Duve, C. Blueprint For a Cell: The Nature and Origin of Life (Neil Patterson Publishers, Burlington, NC) (1991).

12 Liu, R. \& Orgel, L. E. Oxidative acylation using thioacids. Nature 389, 52-54 (1997).

13 Weber, A. L. Prebiotic amino acid thioester synthesis: Thiol-dependent amino acid synthesis from formose substrates (formaldehyde and glycolaldehyde) and ammonia. Orig. Life Evol. Biosph. 28, 259-270 (1998).

14 Bowler, F. R. et al. Prebiotically plausible oligoribonucleotide ligation facilitated by chemoselective acetylation. Nat. Chem. 5, 383-389 (2013).

15 Keefe, A. D. \& Miller, S. L. Was ferrocyanide a prebiotic reagent? Orig. Life Evol. Biosph. 26, 111129, (1996).

16 Maurel, M.-C. \& Orgel, L. E. Oligomerization of $\alpha$-thioglutamic acid. Orig. Life Evol. Biosph. 30, 423-430 (2000).

17 Leman, L., Orgel, L. \& Ghadiri, M. R. Carbonyl sulfide-mediated prebiotic formation of peptides. Science 306, 283-286 (2004).

18 Islam, S., Bučar, D.-K. \& Powner, M. W. Prebiotic selection and assembly of proteinogenic amino acids and natural nucleotides from complex mixtures. Nat. Chem. 9, 584-589 (2017).

19 Stairs, S. et al. Divergent prebiotic synthesis of pyrimidine and 8-oxo-purine ribonucleotides. Nat. Commun. 8, 15270 (2017).

20 Islam, S., \& Powner, M. W. Prebiotic systems chemistry: Complexity overcoming clutter. Chem 2, 470-501 (2017).

21 Roberts, S. J. et al. Selective prebiotic conversion of pyrimidine and purine anhydronucleosides into Watson-Crick base-pairing arabino-furanosyl nucleosides in water. Nat. Commun. 9, 4073 (2018). Chadha, M. S., Replogle, L., Flores, J. \& Ponnamperuma, C. Possible role of aminoacetonitrile in chemical evolution. Bioorg. Chem. 1, 269-274 (1971).

23 Paventi, M. \& Edward, J. T. Preparation of $\alpha$-aminothioamides from aldehydes. Can. J. Chem. 65, 282-289 (1987). 
24 Sheehan, J. C. \& Johnson, D. A. The synthesis and reactions of N-acyl thiol amino acids. J. Am. Chem. Soc. 74, 4726-4727 (1952).

25 Leman, L. J. \& Ghadiri, M. R. Potentially prebiotic synthesis of $\alpha$-amino thioacids in water. Synlett 28, 68-72 (2017).

26 Kajihara, Y. et al. Regioselective $\alpha$-peptide bond formation through oxidation of amino thioacids. Biochemistry 58, 1672-1678 (2019).

27 Steinberg, S. M. \& Bada, J. L. Peptide decomposition in the neutral pH region via the formation of diketopiperazines. J. Org. Chem. 48, 2295-2298 (1983).

28 Radzicka, A. \& Wolfenden, R. Rates of uncatalyzed peptide bond hydrolysis in neutral solution and the transition state affinities of proteases. J. Am. Chem. Soc. 118, 6105-6109 (1996).

29 Dawson, P., Muir, T., Clark-Lewis, I. \& Kent, S. Synthesis of proteins by native chemical ligation. Science 266, 776-779 (1994).

30 Matteo, V., Hubert, G. \& Paolo, B. Native chemical ligation with aspartic and glutamic acids as $C$ terminal residues: Scope and limitations. Eur. J. Org. Chem. 2003, 3267-3272 (2003).

31 Danger, G. et al. 5(4H)-Oxazolones as intermediates in the carbodiimide- and cyanamide-promoted peptide activations in aqueous solution. Angew. Chem. Int. Ed. 52, 611-614 (2013).

32 Griesser, H., Bechthold, M., Tremmel, P., Kervio, E. \& Richert, C. Amino acid-specific, ribonucleotide-promoted peptide formation in the absence of enzymes. Angew. Chem. Int. Ed. 56, 1224-1228 (2017).

33 Zhang, L. \& Tam, J. P. Lactone and lactam library synthesis by silver ion-assisted orthogonal cyclization of unprotected peptides. J. Am. Chem. Soc. 121, 3311-3320 (1999).

\section{Acknowledgments}

We thank the Engineering and Physical Sciences Research Council (EP/K004980/1, EP/P020410/1), the Simons Foundation $(318881,493895)$ and Volkswagen Foundation (94743) for financial support. The authors thank Dr. K. Karu (UCL Mass Spectrometry Facility), Mr. E. Samuel (Mass Spectrometry, UCL School of Pharmacy), and Dr. A. E. Aliev (NMR spectroscopy) for their assistance.

\section{Author Contributions}

M.W.P. conceived the research. P.C., S.I. and M.W.P. designed and analysed the experiments. P.C. and S.I. contributed equally to the experiments. S.I. wrote the Supplementary Information. M.W.P and S.I. wrote the paper and Supplementary Discussion. 


\section{Competing interests}

The authors declare no competing financial interests.

\section{Additional information}

Extended Data is available for this paper at $[A D D U R L]$.

Supplementary Information is available for this paper at [ADD URL].

Reprints and permissions information is available at www.nature.com/reprints.

Correspondence and requests for materials should be addressed to M.W.P. [matthew.powner@ucl.ac.uk] 
a

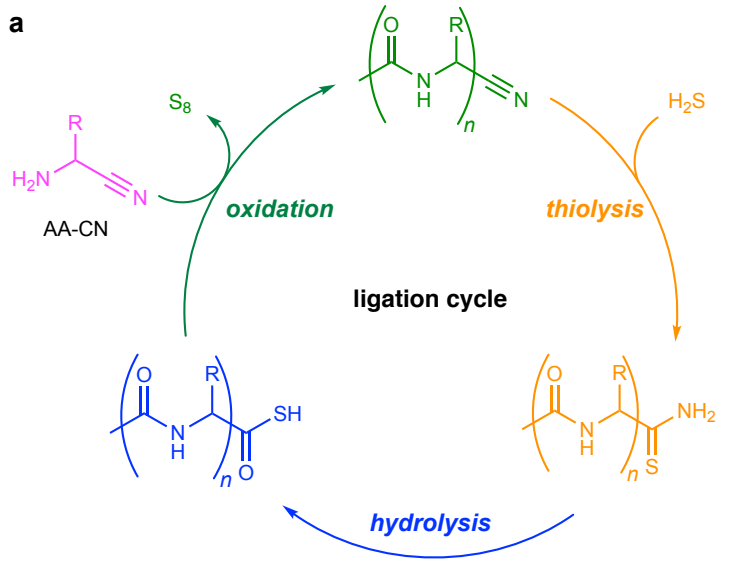

b<smiles></smiles>

$\mathrm{AcSH}\left\lfloor\left[\mathrm{Fe}(\mathrm{CN})_{6}\right]^{3-}\right.$

$\mathrm{N}_{\mathrm{H}} \stackrel{\mathrm{H} S}{\longrightarrow}$

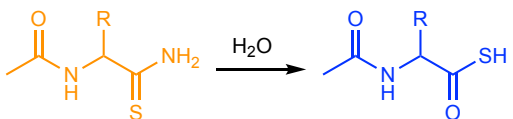

Ac-AA-CN Ac-AA-SNH

Ac-AA-SH<smiles>[R]C(N)C(=O)NC([R])C(=O)N[O+]</smiles><smiles>[R]C(NC(=O)O[Na])C(=O)NC([R])C(=O)N[CH]</smiles>

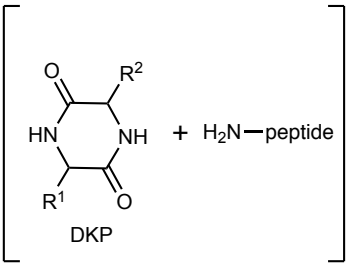

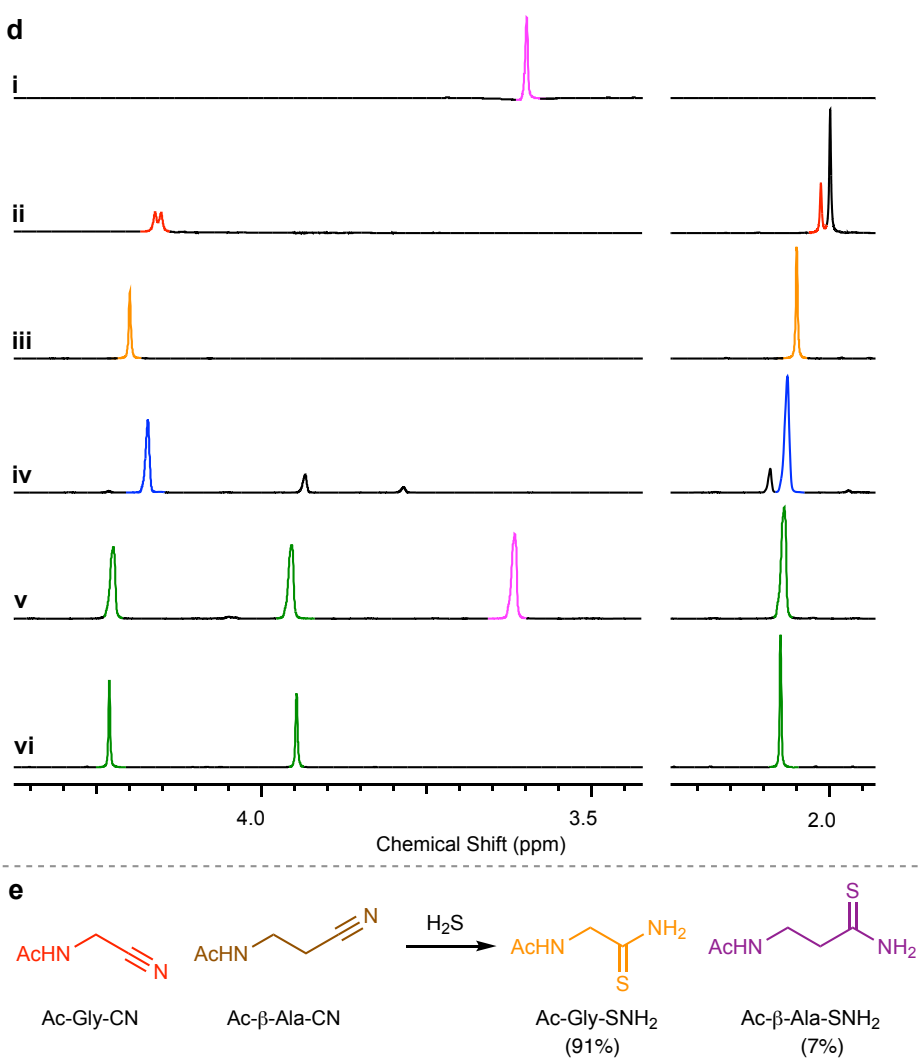

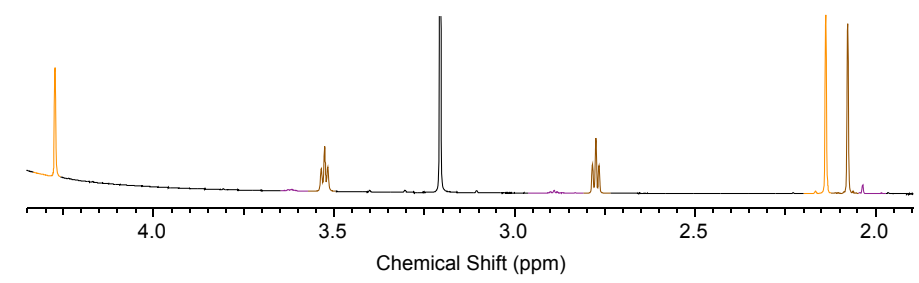

Figure 1 | Sulfide-mediated $\boldsymbol{\alpha}$-aminonitrile ligation a. Iterative AA-CN ligation to give $N$-acetyl peptide nitriles (Ac- $\mathrm{AA}_{n}-\mathrm{CN}$; green) by sequential thiolysis, hydrolysis and $\alpha$-aminonitrile ligation. $\mathbf{b}$. The thiolysis of $\alpha$-aminonitrile (AA-CN, magenta) to yield $\alpha$-aminothioacid (AA-SH, black) is not observed, whereas the thiolysis of $N$-acetyl aminonitrile (Ac-AA-CN, red) to $\alpha$-amidoacyl thioacid (Ac-AA-SH, blue) is facile. c. Iterative truncation of peptides by DKP excision is blocked by $\mathrm{N}$-acylation. d. ${ }^{1} \mathrm{H}$ NMR spectra $(600 \mathrm{MHz}$, $\mathrm{H}_{2} \mathrm{O} / \mathrm{D}_{2} \mathrm{O}$ 98:2, $25{ }^{\circ} \mathrm{C}$ ) showing i. Glycine nitrile (Gly-CN, magenta). ii. Ac-Gly-CN (Quant., red) synthesised by reaction of Gly-CN $(50 \mathrm{mM})$ with thioacetic acid (3 equiv.) and $\mathrm{K}_{3}\left[\mathrm{Fe}(\mathrm{CN})_{6}\right](9$ equiv.) in water at $\mathrm{pH} 9$ at room temperature after 10 min. iii. Ac-Gly-SNH 2 (Quant., orange) synthesised by the reaction of Ac-Gly-CN $(50 \mathrm{mM})$ with $\mathrm{H}_{2} \mathrm{~S}$ (10 equiv.) in water at $\mathrm{pH} 9$ at room temperature after $1 \mathrm{~d}$. iv. Ac-Gly-SH (81\%, blue) synthesised by hydrolysis of Ac-Gly-SNH $2(50 \mathrm{mM})$ at $\mathrm{pH} 9$ and $60{ }^{\circ} \mathrm{C}$ after $1 \mathrm{~d}$. v. Ac-Gly $2-\mathrm{CN}$ (Quant., green) synthesised by reaction of Ac-Gly-SH $(50 \mathrm{mM})$ with Gly-CN (2 equiv., magenta) and $\mathrm{K}_{3}\left[\mathrm{Fe}(\mathrm{CN})_{6}\right]$ (3 equiv.) in water at $\mathrm{pH} 9$ and room temperature after $20 \mathrm{~min}$. vi. Pure AcGly 2 -CN. e. ${ }^{1} \mathrm{H}$ NMR spectrum $\left(600 \mathrm{MHz}, \mathrm{H}_{2} \mathrm{O} / \mathrm{D}_{2} \mathrm{O} 98: 2,25{ }^{\circ} \mathrm{C}\right)$ showing the reaction of homologous amidonitriles Ac-Gly-CN (red) and Ac- $\beta$-Ala-CN (brown) with $\mathrm{H}_{2} \mathrm{~S}$ (10 equiv., $\mathrm{pH} 9$, room temperature, $1 \mathrm{~d}$ ), which strongly favours thiolysis of the proteinogenic glycyl residue to yield Ac-Gly-SNH 2 (orange) (Supplementary Fig. 19). 
Table 1 | $\alpha$-Amidothioacid synthesis and $\alpha$-aminonitrile ligation

\begin{tabular}{|c|c|c|c|c|c|}
\hline \multirow{2}{*}{ Entry } & \multirow{2}{*}{ AA } & \multicolumn{4}{|c|}{ Yield (\%) } \\
\hline & & Ac-AA-CNa & Ac-AA-SNH ${ }_{2}{ }^{b}$ & Ac-AA-SH ${ }^{\mathrm{C}}$ & Ac-AA-Gly-CN \\
\hline 1 & Gly & 99 & 99 & 81 & 99 \\
\hline 2 & Ala & 99 & 99 & 85 & 93 \\
\hline 3 & Arg & 99 & 99 & 51 & $64^{\mathrm{e}}$ \\
\hline 4 & Leu & 99 & 99 & 77 & 93 \\
\hline 5 & Met & 99 & 99 & 70 & 80 \\
\hline 6 & Phe & 99 & 99 & 84 & 78 \\
\hline 7 & Pro & 99 & 99 & 72 & 82 \\
\hline 8 & Ser & 99 & 99 & 61 & $87^{f}$ \\
\hline 9 & Val & 99 & 99 & 8 & 92 \\
\hline
\end{tabular}

${ }^{1} \mathrm{H}$ NMR yields are determined with an internal NMR standard. See Extended Data Table 5 for further examples of $\alpha$-aminonitrile ligations.

${ }^{a}$ Acetylation of AA-CN $(50 \mathrm{mM})$ with $\mathrm{AcSH}(150 \mathrm{mM})$ and $\mathrm{K}_{3}\left[\mathrm{Fe}(\mathrm{CN})_{6}\right](450 \mathrm{mM})$ in water (pH 9; room temperature; $<20 \mathrm{~min}$ ).

${ }^{\text {bThiolysis of Ac-AA-SNH}} 2(50 \mathrm{mM})$ by $\mathrm{H}_{2} \mathrm{~S}$ (10 equiv., $\mathrm{pH} 9$, room temperature) in water (Supplementary Fig. 39-52, 64, 80).

${ }^{c}$ Hydrolysis of Ac-AA-SNH $2(50 \mathrm{mM})$ to Ac-AA-SH in water with $\mathrm{H}_{2} \mathrm{~S}\left(500 \mathrm{mM} ; \mathrm{pH} 9,60{ }^{\circ} \mathrm{C}\right)$ (Supplementary Fig. 53-59, 64, 80).

${ }^{\mathrm{d}}$ Ligation of Ac-AA-SH $(50 \mathrm{mM})$ to Gly-CN $(100 \mathrm{mM})$ in water with $\mathrm{K}_{3}\left[\mathrm{Fe}(\mathrm{CN})_{6}\right](150 \mathrm{mM}$; pH 9, room temperature), unless stated otherwise.

'Yield for the coupling of Ac-Arg-SH (46 mM) with Gly-CN $(91 \mathrm{mM})$ and $\mathrm{K}_{3}\left[\mathrm{Fe}(\mathrm{CN})_{6}\right](136 \mathrm{mM})$.

${ }^{f}$ Yield for the coupling of Ac-Ser-SH $(30 \mathrm{mM})$ with Gly-CN $(61 \mathrm{mM})$ and $\mathrm{K}_{3}\left[\mathrm{Fe}(\mathrm{CN})_{6}\right](92 \mathrm{mM})$. 
Table 2 | Synthesis of oligomeric $N$-acetyl peptides and peptide nitriles by oxidative fragment ligation

\begin{tabular}{|c|c|c|c|}
\hline Entry & $\left(\mathrm{AA}^{1}\right)_{n}$ & $\left(\mathrm{AA}^{2}\right)_{m}-\mathrm{X}$ & 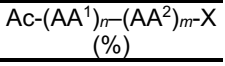 \\
\hline 1 & Gly & Gly-CN & $71^{\mathrm{a}}$ \\
\hline 2 & $\mathrm{Gly}_{2}$ & Gly-CN & $71^{\mathrm{b}}$ \\
\hline 3 & $\mathrm{Gly}_{3}$ & Gly-CN & $63^{c}$ \\
\hline 4 & $\mathrm{Gly}_{4}$ & Gly-CN & $41^{d}$ \\
\hline 5 & $\mathrm{Gly}_{3}$ & $\mathrm{Ala}_{3}-\mathrm{OH}$ & 65 \\
\hline 6 & $\mathrm{Gly}_{3}$ & Arg-Gly-Asp-OH & 76 \\
\hline 7 & $\mathrm{Gly}_{3}$ & $\mathrm{Gly}_{3}-\mathrm{OH}$ & 90 \\
\hline 8 & $\mathrm{Gly}_{3}$ & $\mathrm{Gly}_{3}-\mathrm{CN}$ & $>95$ \\
\hline 9 & $\mathrm{Gly}_{3}$ & $\mathrm{Gly}_{2}-\mathrm{His}-\mathrm{OH}$ & $90^{\mathrm{e}}$ \\
\hline 10 & $\mathrm{Gly}_{3}$ & $\mathrm{Leu}_{3}-\mathrm{OH}$ & 70 \\
\hline 11 & $\mathrm{Gly}_{3}$ & Met-Ala-Ser-OH & 75 \\
\hline 12 & $\mathrm{Gly}_{3}$ & Phe-Glyz-OH & 74 \\
\hline 13 & $\mathrm{Gly}_{5}$ & $\mathrm{Ala}_{3}-\mathrm{OH}$ & 74 \\
\hline 14 & $\mathrm{Gly}_{5}$ & $\mathrm{Gly}_{2}-\mathrm{His}-\mathrm{OH}$ & 80 \\
\hline 15 & Gly 6 & $\mathrm{Gly}_{3}-\mathrm{CN}$ & $43^{h}$ \\
\hline 16 & Gly 5 & Gly5-OH & $79\left(66^{i}\right)$ \\
\hline 17 & Gly6 & Gly5-OH & $>95^{\mathrm{j}}\left(92^{\mathrm{i}}\right)$ \\
\hline
\end{tabular}

Ferricyanide-mediated oxidative coupling of Ac- $\left(\mathrm{AA}^{1}\right)_{n}-\mathrm{SH}$ with $\left(\mathrm{AA}^{2}\right)_{m}-\mathrm{X}\left(\mathrm{X}=\mathrm{CN}\right.$ or $\left.\mathrm{CO}_{2} \mathrm{H}\right)$ to produce oligopeptides Ac- $\left(\mathrm{AA}^{1}\right)_{n}-\left(\mathrm{AA}^{2}\right)_{m}$-X. Yields for oxidative coupling of thioacid Ac- $\left(\mathrm{AA}^{1}\right)_{n}$-SH $(25 \mathrm{mM})$ with peptide $\left(\mathrm{AA}^{2}\right)_{m}-\mathrm{X}(25 \mathrm{mM}, \mathrm{pD} 9.5)$ and $\mathrm{K}_{3}\left[\mathrm{Fe}(\mathrm{CN})_{6}\right](75 \mathrm{mM})$ in $\mathrm{D}_{2} \mathrm{O}$ at room temperature, unless stated otherwise. See Supplementary Table 15 for further details.

${ }^{\mathrm{a}-\mathrm{d}} \mathrm{Ac}-\mathrm{Gly}_{n}-\mathrm{CN}$ synthesis by iterative ligation after two, three, four and five cycles of thiolysis, hydrolysis and ligation (Supplementary Fig. 209-211).

${ }^{\mathrm{e}}$ Coupling of Ac-Gly3-SH (30 mM) with Gly2-His-OH (25 mM, pD 9.5) with $\mathrm{K}_{3}\left[\mathrm{Fe}(\mathrm{CN})_{6}\right](75 \mathrm{mM})$.

hYield of Ac-Glyg-CN is given after four sequential steps from Ac-Gly $3-\mathrm{SH}$.

iYield determined by product isolation.

${ }^{\mathrm{j} C}$ Coupling of Ac-Gly6-SH (3.13 mM) and Gly5-OH (6.25 mM). 
Table 3 | Chemoselective synthesis of $N$-acetyl dipeptides

\begin{tabular}{ccc}
\hline Entry & AA & Ac-Gly-AA-OH (\%) \\
\hline 1 & Gly & 94 \\
2 & Ala & 83 \\
3 & Arg & 88 \\
4 & Asn & 81 \\
5 & Asp & 89 \\
6 & Cys & $80^{\mathrm{a}}$ \\
7 & Gln & 90 \\
8 & Glu & 92 \\
9 & His & 95 \\
10 & Ile & 84 \\
11 & Leu & 86 \\
12 & Lys & $94^{\mathrm{b}}$ \\
13 & Met & 95 \\
14 & Phe & 90 \\
15 & Pro & 89 \\
16 & Ser & 85 \\
17 & Thr & 81 \\
18 & Trp & 71 \\
19 & Tyr & $23^{\mathrm{c}}$ \\
20 & Val & 84 \\
\hline & & \\
\hline & & \\
\hline 1 & &
\end{tabular}

Yields are given for the products of oxidative coupling of Ac-Gly-SH (50 mM) with $\alpha$-amino acid AA (150 $\mathrm{mM})$ with $\mathrm{K}_{3}\left[\mathrm{Fe}(\mathrm{CN})_{6}\right](150 \mathrm{mM})$ in water at room temperature and $\mathrm{pH}$ 9.5. ${ }^{1} \mathrm{H}$ NMR yields determined with an internal NMR standard.

${ }^{a}$ Yield observed using $\mathrm{K}_{3}\left[\mathrm{Fe}(\mathrm{CN})_{6}\right](300 \mathrm{mM})$, followed by methanethiol $(600 \mathrm{mM}$, pH 10.8) reduction (see Extended Data Fig. 1a and Supplementary Figure 112-114).

${ }^{\mathrm{b}}$ The observed ratio of mono- and di-acylated products varies with solution $\mathrm{pH}$ (see Extended Data Fig. $1 \mathrm{~b}$ for $\alpha$-selectivity of Lys ligation at $\mathrm{pH} 7.5$, and Supplementary Table 11).

${ }^{c} \mathrm{~L}-\mathrm{Tyrosine}$ (Tyr) exhibits extremely low solubility in water $(6.5 \mathrm{mM}, \mathrm{pH} 9.5$, room temperature (see Supplementary Table 8). 


\section{Methods}

General and Safety Information.

Reagents and solvents were obtained and used without further purification, unless specified. Sodium hydrosulfide hydrate $\left[\mathrm{NaSH} \cdot \times \mathrm{H}_{2} \mathrm{O}(50 \%\right.$ purity) $]$ and sodium sulfide $\left[\mathrm{Na}_{2} \mathrm{~S}(>97 \%)\right]$ were used without purification. Deionized water was obtained from an Elga Option 3 purification system. NMR spectra were recorded on Bruker NMR spectrometers AVANCE Neo 700, AVANCE III 600, AVANCE III 400 and AVANCE 300 , equipped with a Bruker room temperature $5 \mathrm{~mm}$ multinuclear gradient probe $(700 \mathrm{MHz}), 5 \mathrm{~mm} \mathrm{DCH}$ cryoprobe $(600 \mathrm{MHz})$ and a gradient probe $(400$ and $300 \mathrm{MHz})$. Where noted, solvent suppression pulse sequence with presaturation and spoil gradients was used to obtain ${ }^{1} \mathrm{H}$ NMR spectra (noesygppr1d, Bruker) and ${ }^{1} \mathrm{H}-{ }^{13} \mathrm{C}$ HMBC NMR spectra (hmbcgplpndprqf, Bruker). Coupling constants are reported in Hertz (Hz). Spectra were recorded at 298 K. Infrared spectra (IR) were recorded on a Shimadzu IR Tracer 100 FT-IR spectrometer as a solid or liquid. Absorption maxima are reported in wavenumber $\left(\mathrm{cm}^{-1}\right)$. Mass spectra and accurate mass measurements were recorded on a Waters LCT Premier QTOF connected to a Waters Autosampler Manager 2777C, Thermo Finnigan MAT900, and an Agilent LC connected to an Agilent 6510 QTOF mass spectrometer. HPLC analysis was carried out using an Agilent Infinity 1260 LC system. Solution $\mathrm{pH}$ values were measured using a Mettler Toledo Seven Compact $\mathrm{pH}$ meter with a Mettler Toledo InLab semimicro $\mathrm{pH}$ probe. The $\mathrm{pH}$ readings for $\mathrm{H}_{2} \mathrm{O}$ and $\mathrm{H}_{2} \mathrm{O} / \mathrm{D}_{2} \mathrm{O}$ (9:1) solutions are reported uncorrected. WARNING: Hydrogen cyanide $(\mathrm{HCN})$ and hydrogen sulfide $\left(\mathrm{H}_{2} \mathrm{~S}\right)$ are highly toxic poisons by inhalation and ingestion. They generate poisonous gas at neutral or acidic $\mathrm{pH}\left[\mathrm{HCN}\left(\mathrm{p} K_{\mathrm{a}}=9.2\right)\right.$ and $\left.\mathrm{H}_{2} \mathrm{~S}\left(\mathrm{p} K_{\mathrm{a}}=7.1\right)\right]$. Solutions containing cyanide or (hydro)sulfide, or compounds which may generate these must be handled in a wellventilated fumehood equipped with appropriate chemical quenches, such as sodium hypochlorite (bleach) or iron(II) sulfate solution.

\section{General procedures.}

Acetylation of $\alpha$-aminonitriles with thioacetate. $\alpha$-Aminonitrile hydrochloride (AA-CN.HCl; $50 \mathrm{mM}$ ) and potassium thioacetate (AcSK; $150 \mathrm{mM})$ were dissolved in $\mathrm{H}_{2} \mathrm{O}(2 \mathrm{~mL})$ and the solution was adjusted to $\mathrm{pH}$ 9.0 with $\mathrm{NaOH}$. Potassium hexacyanoferrate(III) $\left(\mathrm{K}_{3}\left[\mathrm{Fe}(\mathrm{CN})_{6}\right] ; 450 \mathrm{mM}\right)$ was added, and the solution stirred at room temperature for $20 \mathrm{~min}$. The solution was adjusted to $\mathrm{pH} 9.0$, centrifuged, and NMR spectra of the supernatant were acquired. Yields are reported in Table 1 and characterisation data in Supplementary Information.

Thiolysis of $\mathrm{N}$-acetylaminonitriles. $\mathrm{N}$-Acetylaminonitrile (Ac-AA-CN; $50 \mathrm{mM})$ and $\mathrm{NaSH} \times \times \mathrm{H}_{2} \mathrm{O}(10$ equiv.) were dissolved in degassed $\mathrm{H}_{2} \mathrm{O} / \mathrm{D}_{2} \mathrm{O}(98: 2,50 \mathrm{~mL})$. The solution was adjusted to $\mathrm{pH} 9.0$ and stirred at room 
temperature for $24 \mathrm{~h}$. NMR spectra were periodically acquired, until complete conversion of Ac-AA-CN to Ac-AA- $\mathrm{SNH}_{2}$ was observed. The solution was sparged with argon for $15 \mathrm{~min}$ at $\mathrm{pH} 5.0$ and concentrated in vacuo. The residue was purified by flash column chromatography to afford Ac-AA- $\mathrm{SNH}_{2}$. Yields are reported in Table 1 and characterisation data in Supplementary Information.

Hydrolysis of $\mathrm{N}$-acetylaminothioamide to $\mathrm{N}$-acetylaminoacyl thioacids. Ac-AA-SNH $\mathrm{S}_{2}(50 \mathrm{mM}), \mathrm{NaSH} \cdot \times \mathrm{H}_{2} \mathrm{O}$ (10 equiv.) and methylsulfonylmethane (MSM; $50 \mathrm{mM})$ were dissolved in degassed $\mathrm{H}_{2} \mathrm{O} / \mathrm{D}_{2} \mathrm{O}(98: 2,1 \mathrm{~mL})$, and the solution was adjusted to $\mathrm{pH} 9.0$ with $\mathrm{NaOH} / \mathrm{HCl}$. The solution was incubated at $60{ }^{\circ} \mathrm{C}$, whilst maintaining the solution at $\mathrm{pH} 9.0$ with $\mathrm{NaOH} / \mathrm{HCl}$, and $\mathrm{NMR}$ spectra were periodically acquired until complete consumption of Ac-AA-SNH$H_{2}$ was observed. The Ac-AA-SH was confirmed by ${ }^{1} \mathrm{H}-{ }^{13} \mathrm{C} \mathrm{HMBC}$ NMR analysis, spiking or comparison of NMR data with pure synthetic standards. The reaction mixture was quantified using MSM as an internal standard. Yields are reported in Table 1 and characterisation data in Supplementary Information.

Oxidative coupling of Ac-Gly-SH with $\alpha$-amino acids or $\alpha$-amino amides. $\alpha$-Amino acid (AA) or $\alpha$-amino amide $\left(\mathrm{AA}-\mathrm{NH}_{2}\right)(150 \mathrm{mM})$ was dissolved in degassed $\mathrm{H}_{2} \mathrm{O} / \mathrm{D}_{2} \mathrm{O}(98: 2 ; 1 \mathrm{~mL})$ and the solution was adjusted to $\mathrm{pH} 9.5$ with $\mathrm{HCl} / \mathrm{NaOH}$. Ac-Gly-SH $(50 \mathrm{mM})$ was added and the total volume was adjusted to $2 \mathrm{~mL}$ with $\mathrm{H}_{2} \mathrm{O} / \mathrm{D}_{2} \mathrm{O}$ (98:2). Potassium hexacyanoferrate(III) $\left(\mathrm{K}_{3}\left[\mathrm{Fe}(\mathrm{CN})_{6}\right], 150 \mathrm{mM}\right)$ was added and the solution was stirred at room temperature for 20 min whilst maintaining the solution at $\mathrm{pH} 9.5$ with $\mathrm{NaOH}$. The resulting suspension was centrifuged and the supernatant was analysed by $1 \mathrm{D}$ and 2D NMR spectroscopy $\left({ }^{1} \mathrm{H}-{ }^{1} \mathrm{H}\right.$ COSY; ${ }^{1} \mathrm{H}-{ }^{13} \mathrm{C}$ HSQC; ${ }^{1} \mathrm{H}-{ }^{13} \mathrm{C}$ HMBC) in $\mathrm{H}_{2} \mathrm{O} / \mathrm{D}_{2} \mathrm{O}$ (98:2). The yield was quantified using MSM as an internal standard. The ligation product (Ac-Gly-AA-X; $\mathrm{X}=\mathrm{OH}$ or $\mathrm{NH}_{2}$ ) was confirmed by ${ }^{1} \mathrm{H}-{ }^{13} \mathrm{C} \mathrm{HMBC}$ NMR spectral analysis and high resolution mass spectrometry (HRMS). Reaction mixtures were lyophilised and dissolved in DMSO- $d_{6}$ or $\mathrm{CD}_{3} \mathrm{OD}$ for further NMR spectral analysis if ${ }^{1} \mathrm{H}-{ }^{13} \mathrm{C}$ HMBC cross-correlation peaks were obscured by the HOD resonance during original NMR analysis in $\mathrm{H}_{2} \mathrm{O} / \mathrm{D}_{2} \mathrm{O}$ (98:2). Yields and HRMS data are given in Table 3 and Supplementary Table 8 (Ac-Gly-AA-OH) and Extended Data Table 4 and Supplementary Table 9 (Ac-Gly-AA-NH$)$, and characterisation data in Supplementary Information.

Oxidative coupling of $\alpha$-aminoacetyl thioacids with $\alpha$-aminonitriles. $\alpha$-Aminonitrile (AA $\left.{ }^{2}-\mathrm{CN} ; 100 \mathrm{mM}\right)$ was dissolved in degassed $\mathrm{H}_{2} \mathrm{O} / \mathrm{D}_{2} \mathrm{O}(98: 2 ; 2 \mathrm{~mL})$ and the solution was adjusted to $\mathrm{pH} 9.0$ with $\mathrm{HCl} / \mathrm{NaOH}$. Ac$\mathrm{AA}^{1}-\mathrm{SH}(50 \mathrm{mM})$ was added and the total volume was adjusted to $2 \mathrm{~mL}$ with $\mathrm{H}_{2} \mathrm{O} / \mathrm{D}_{2} \mathrm{O}(98: 2)$. Potassium hexacyanoferrate(III) $\left(\mathrm{K}_{3}\left[\mathrm{Fe}(\mathrm{CN})_{6}\right] ; 150 \mathrm{mM}\right)$ was added and the solution was stirred at room temperature for 20 min. The $\mathrm{pH}$ was readjusted to $\mathrm{pH} 9.0$ using $\mathrm{NaOH}$. The resulting suspension was centrifuged and the 
supernatant was analysed by $1 \mathrm{D}$ and $2 \mathrm{D}$ NMR spectroscopy $\left({ }^{1} \mathrm{H}-{ }^{1} \mathrm{H}\right.$ COSY; ${ }^{1} \mathrm{H}-{ }^{13} \mathrm{C} \mathrm{HSQC} ;{ }^{1} \mathrm{H}-{ }^{13} \mathrm{C}$ HMBC $)$ in $\mathrm{H}_{2} \mathrm{O} / \mathrm{D}_{2} \mathrm{O}$ (98:2). The reaction mixture was quantified using MSM as an internal standard. The ligation product $\mathrm{Ac}-\mathrm{AA}^{1}-\mathrm{AA}^{2}-\mathrm{CN}$ was confirmed by ${ }^{1} \mathrm{H}-{ }^{13} \mathrm{C}$ HMBC NMR spectral analysis and HRMS. Reaction mixtures were diluted with DMSO- $d_{6}\left(1: 49: 50 ; \mathrm{D}_{2} \mathrm{O} / \mathrm{H}_{2} \mathrm{O} / \mathrm{DMSO}-d_{6}\right)$, or lyophilised and dissolved in DMSO$d_{6}$ or $\mathrm{CD}_{3} \mathrm{OD}$ for further NMR spectral analysis if ${ }^{1} \mathrm{H}-{ }^{13} \mathrm{C}$ HMBC cross-correlation peaks were obscured by the HOD resonance during original NMR analysis in $\mathrm{H}_{2} \mathrm{O} / \mathrm{D}_{2} \mathrm{O}$ (98:2). Yields and HRMS data are given in Table 1, Extended Data Table 5, and Supplementary Table 7, and characterisation data in Supplementary Information.

Preparative oxidative coupling of $\alpha$-aminoacetyl thioacids with $\alpha$-aminonitriles. $\alpha$-Aminonitrile (AA ${ }^{2}-\mathrm{CN}$; $100 \mathrm{mM}$ ) was dissolved in degassed $\mathrm{H}_{2} \mathrm{O}(5 \mathrm{~mL})$ and the solution $\mathrm{pH}$ was adjusted to $\mathrm{pH} 9.0$ with $\mathrm{NaOH}$. Ac$\mathrm{AA}^{1}$-SH $(50 \mathrm{mmol})$ was added and total volume was adjusted to $10 \mathrm{~mL}$ with $\mathrm{H}_{2} \mathrm{O}$. Potassium hexacyanoferrate(III) $\left(\mathrm{K}_{3}\left[\mathrm{Fe}(\mathrm{CN})_{6}\right] ; 150 \mathrm{mM}\right)$ was added and the solution was stirred at room temperature for $20 \mathrm{~min}$. The solution was then extracted with ethyl acetate $(3 \times 25 \mathrm{~mL})$. The combined organic layers were washed with $\mathrm{HCl}(0.1 \mathrm{M}, 25 \mathrm{~mL}), \mathrm{NaHCO}_{3}$ (saturated; $25 \mathrm{~mL}$ ) and brine (saturated; $25 \mathrm{~mL}$ ), dried over $\mathrm{MgSO}_{4}$, filtered, and concentrated in vacuo. The crude residue was purified by flash column chromatography to give ligation product (Ac-AA ${ }^{1}-\mathrm{AA}^{2}-\mathrm{CN}$ ) as a white solid. Isolated yields and HRMS data are given in Extended Data Table 5 and Supplementary Table 7, and characterisation data in Supplementary Information.

Oxidative peptide fragment ligations. Ac- $\left(\mathrm{AA}^{1}\right)_{n}-\mathrm{SH}(3.1-30.0 \mathrm{mM})$ and $\left(\mathrm{AA}^{2}\right)_{m}-\mathrm{X}\left(\mathrm{X}=\mathrm{CO}_{2} \mathrm{H}\right.$ or $\mathrm{CN} ; 1-$ 2 equiv.) were dissolved in degassed $\mathrm{D}_{2} \mathrm{O}$ and the solution was adjusted to $\mathrm{pD} 9.5$ with $\mathrm{NaOH}$. Potassium hexacyanoferrate(III) $\left(\mathrm{K}_{3}\left[\mathrm{Fe}(\mathrm{CN})_{6}\right] ; 3\right.$ equiv.) was added and the solution was stirred at room temperature for 20 min whilst maintaining the solution at pD 9.5 with $\mathrm{NaOH}$. The resulting suspension was centrifuged and the supernatant was analysed by $1 \mathrm{D}$ and $2 \mathrm{D}$ NMR spectroscopy $\left({ }^{1} \mathrm{H}-{ }^{1} \mathrm{H}\right.$ COSY; ${ }^{1} \mathrm{H}-{ }^{13} \mathrm{C}$ HSQC; ${ }^{1} \mathrm{H}-{ }^{13} \mathrm{C}$ $\mathrm{HMBC})$. The ligation product $\left(\mathrm{Ac}-\left(\mathrm{AA}^{1}\right)_{n}-\left(\mathrm{AA}^{2}\right)_{m}-\mathrm{X} ; \mathrm{X}=\mathrm{CO}_{2} \mathrm{H}\right.$ or $\left.\mathrm{CN}\right)$ was quantified using relative integral analysis by ${ }^{1} \mathrm{H},{ }^{1} \mathrm{H}-{ }^{13} \mathrm{C}$ HMBC NMR spectral analysis, and HRMS. Yields and HRMS data are given in Table 2 and Supplementary Table 15, and characterisation data in Supplementary Information.

\section{Data availability}

All data supporting the findings of this study are available within the main text, Extended Data Tables 1-5, Extended Data Fig. 1, and its Supplementary Information file (Supplementary Discussion, Supplementary Fig. 1-296, Supplementary Table 1-16, experimental details and compound characterisation data).

\section{Extended Data Table $1 \mid \alpha$-Amidothioacid activating agents}




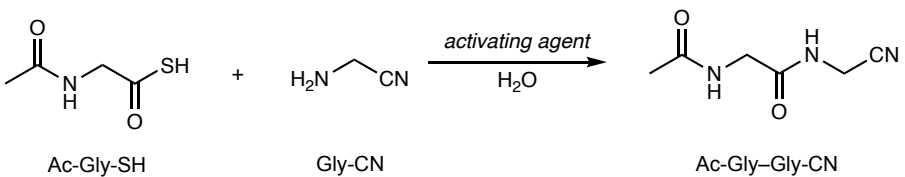

\begin{tabular}{clc}
\hline Activating agent & $\mathrm{pH}$ & Ac-Gly-Gly-CN (\%) \\
\hline \hline$=\mathrm{N}$ & 5.0 & 85 \\
& 7.0 & 74 \\
& 9.0 & 57 \\
\hline & 5.0 & 95 \\
$\mathrm{CuCl}_{2}$ & 7.0 & 70 \\
& 9.0 & 61 \\
\hline & 5.0 & 95 \\
& 7.0 & 94 \\
$\mathrm{~K}_{3}\left[\mathrm{Fe}(\mathrm{CN})_{6}\right]$ & 9.0 & 86 \\
& 5.0 & 91 \\
& 7.0 & 97 \\
& 9.0 & 99 \\
\hline
\end{tabular}

Yields for the oxidative coupling of Ac-Gly-SH $(50 \mathrm{mM})$ and Gly-CN $(100 \mathrm{mM})$ with specified activating agent $(150 \mathrm{mM})$ after $20 \mathrm{~min}$ in water at room temperature. ${ }^{1} \mathrm{H}$ NMR yields determined with an internal NMR standard. 
Extended Data Table 2 | $\alpha$-Aminonitrile ligation in the presence of nucleophilic competitors

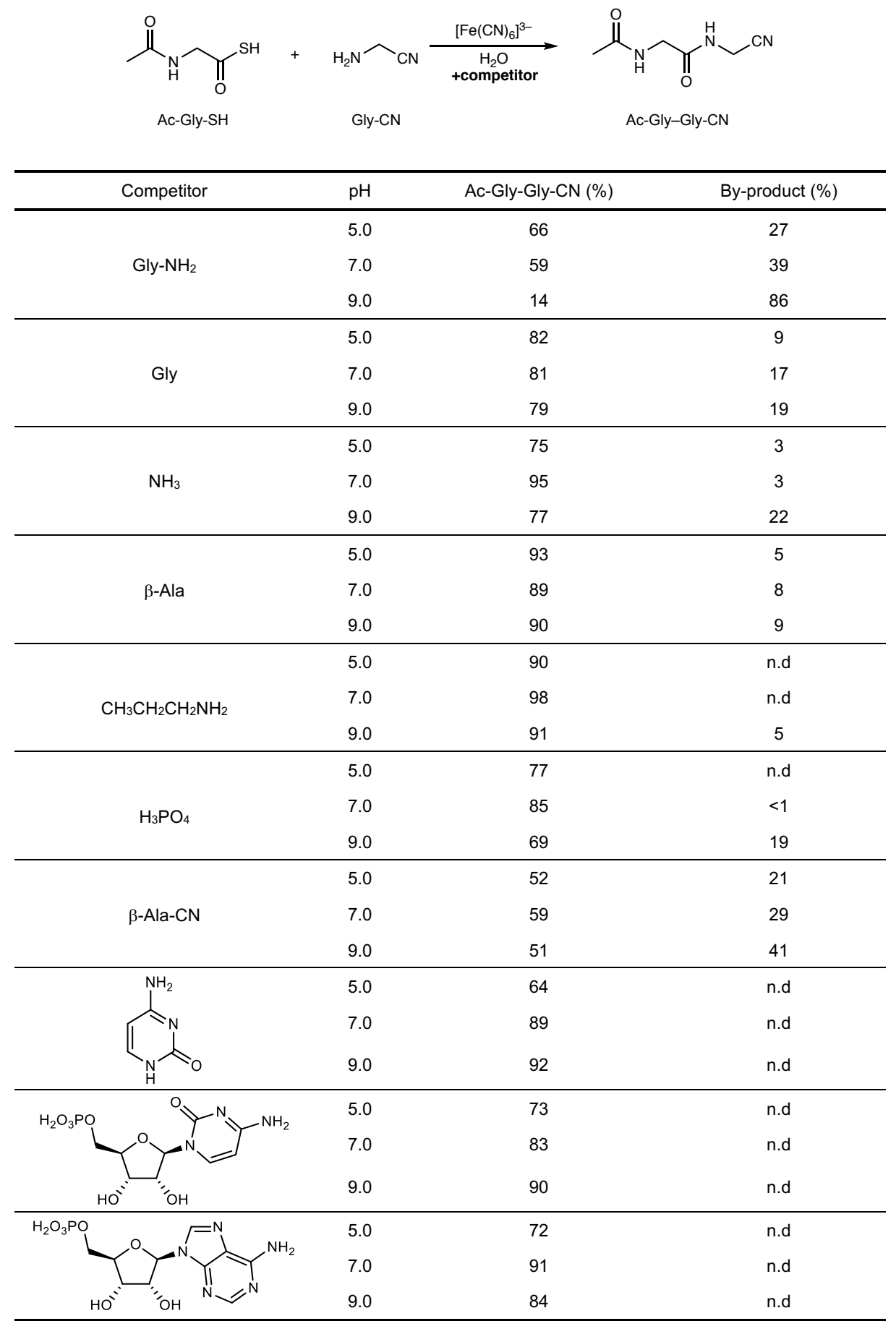

Yields for oxidative coupling of Ac-Gly-SH $(50 \mathrm{mM})$ and Gly-CN $(100 \mathrm{mM})$ with $\mathrm{K}_{3}\left[\mathrm{Fe}(\mathrm{CN})_{6}\right](150 \mathrm{mM})$ in the presence of specified stoichiometric competitor $(100 \mathrm{mM})$ after $20 \mathrm{~min}$ in water at room temperature. ${ }^{1} \mathrm{H}$ NMR yields determined with an internal NMR standard. See Supplementary Figs. 235-244 for further details. n.d $=$ not detected. 
Extended Data Table 3 | $\alpha$-Aminonitrile ligation at various concentrations and temperatures

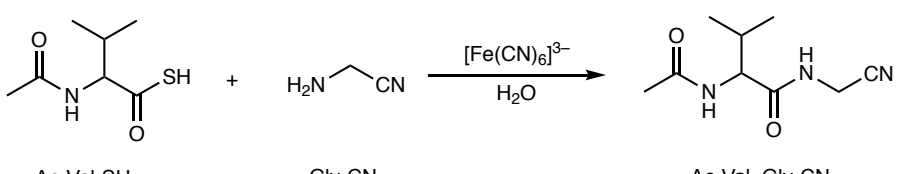

\begin{tabular}{|c|c|c|c|c|c|c|c|c|c|c|c|c|c|c|c|}
\hline \multirow{2}{*}{ Entry } & \multirow{2}{*}{$\begin{array}{c}{[\mathrm{Ac}-\mathrm{Val}-\mathrm{SH}]} \\
(\mathrm{mM})\end{array}$} & \multirow{2}{*}{$\begin{array}{c}\text { [Gly-CN] } \\
(\mathrm{mM})\end{array}$} & \multirow{2}{*}{$\begin{array}{c}{\left[\mathrm{K}_{3}\left[\mathrm{Fe}(\mathrm{CN})_{6}\right]\right]} \\
(\mathrm{mM})\end{array}$} & \multirow{2}{*}{$\begin{array}{l}\text { Temp } \\
\left({ }^{\circ} \mathrm{C}\right)\end{array}$} & \multicolumn{11}{|c|}{ Ac-Val-Gly-CN (\%) } \\
\hline & & & & & $\begin{array}{l}\text { Time } \\
(\mathrm{min})\end{array}$ & 2 & 90 & 180 & 285 & 510 & 750 & 990 & 1260 & 1920 & 2700 \\
\hline 1 & 0.5 & 1 & 1.5 & 23 & & - & 0 & 2 & 4 & 17 & 25 & 31 & 38 & 41 & 45 \\
\hline 2 & 1 & 2 & 3 & 23 & & - & 4 & 16 & 30 & 50 & 57 & 62 & 62 & - & - \\
\hline 3 & 2.5 & 5 & 7.5 & 23 & & - & 29 & 57 & 71 & 80 & 80 & 80 & 81 & - & - \\
\hline 4 & 5 & 10 & 15 & 23 & & - & 75 & 85 & 85 & 86 & 87 & 87 & 87 & - & - \\
\hline 5 & 10 & 20 & 30 & 23 & & - & 83 & 84 & 86 & 86 & 87 & 87 & 87 & - & - \\
\hline 6 & 10 & 20 & 30 & 3 & & - & 50 & - & 75 & - & - & - & 78 & - & - \\
\hline 7 & 10 & 20 & 30 & 60 & & 85 & - & - & - & - & - & - & - & - & - \\
\hline
\end{tabular}

Yields for oxidative coupling of Ac-Val-SH (1 equiv.) and Gly-CN (2 equiv.) with $\mathrm{K}_{3}\left[\mathrm{Fe}(\mathrm{CN})_{6}\right](3$ equiv.) at specified concentration and temperature. ${ }^{1} \mathrm{H}$ NMR yields determined with an internal NMR standard. $(-)=$ not determined. 
Extended Data Table 4 | Chemoselective synthesis of $\mathrm{N}$-acetyl dipeptidyl amides

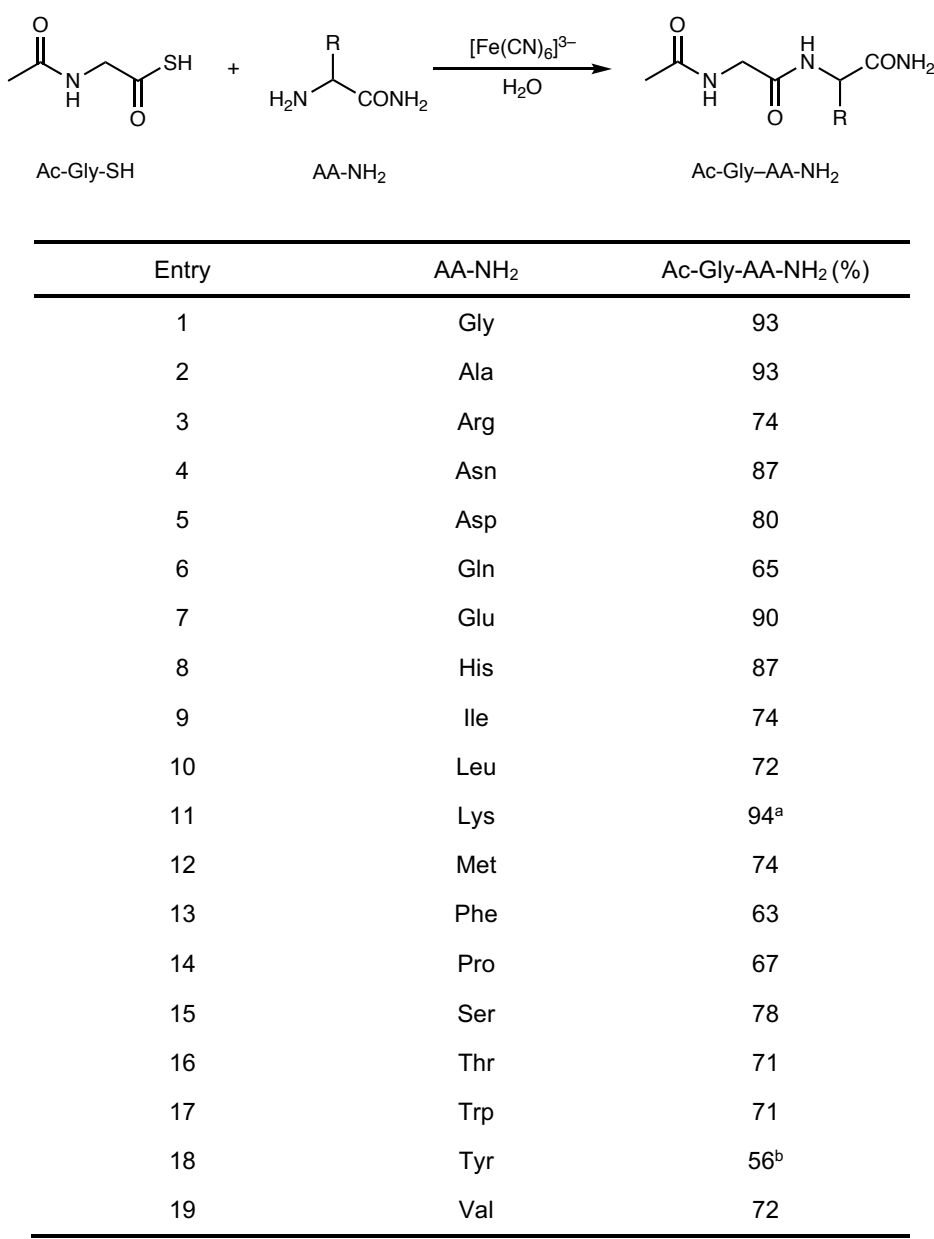

Yields for the oxidative coupling of Ac-Gly-SH $(50 \mathrm{mM})$ and $\mathrm{AA}-\mathrm{NH}_{2}(150 \mathrm{mM})$ with $\mathrm{K}_{3}\left[\mathrm{Fe}(\mathrm{CN})_{6}\right](150$ $\mathrm{mM}$ ) in water at room temperature and $\mathrm{pH} 9.5 .{ }^{1} \mathrm{H}$ NMR yields determined with an internal NMR standard. ${ }^{a}$ The observed ratio of mono- and di-acylated products varies with solution $\mathrm{pH}$ (see Extended Data Fig. $1 \mathrm{~b}$ for $\alpha$-selectivity of $\mathrm{Lys}^{-\mathrm{NH}_{2}}$ ligation at $\mathrm{pH} 7.5$, and Supplementary Tables 12 ).

${ }^{b}$ Reaction carried out at pH 6.5 (see Supplementary Table 9). 
Extended Data Table 5 | Chemoselective synthesis of $\mathrm{N}$-acetyl dipeptidyl nitriles

\begin{tabular}{|c|c|c|c|}
\hline$A c-A A^{1}-S H$ & $A A^{2}-C N$ & & $\mathrm{Ac}-\mathrm{AA}^{1}-\mathrm{AA}^{2}-\mathrm{CN}$ \\
\hline Entry & $A c-A A^{1}-S H$ & $A A^{2}-C N$ & $\begin{array}{c}\mathrm{Ac}^{\mathrm{A}-\mathrm{A} \mathrm{A}^{1}-\mathrm{A} \mathrm{A}^{2}-\mathrm{CN}} \\
(\%)\end{array}$ \\
\hline 1 & Ala & Ala & 85 \\
\hline 2 & Gly & Ala & 95 \\
\hline 3 & Gly & $\operatorname{Arg}$ & 70 \\
\hline 4 & Gly & Asp & 91 \\
\hline 5 & Gly & Glu & 74 \\
\hline 6 & Gly & lle & 87 \\
\hline 7 & Gly & Leu & 89 \\
\hline 8 & Gly & Lys & $93^{a}$ \\
\hline 9 & Gly & Met & 93 \\
\hline 10 & Gly & Phe & 88 \\
\hline 11 & Gly & Pro & 85 \\
\hline 12 & Gly & Ser & 92 \\
\hline 13 & Gly & Thr & 83 \\
\hline 14 & Gly & Val & 94 \\
\hline 15 & lle & Gly & 83 \\
\hline 16 & Lys & Gly & $88^{b}$ \\
\hline 17 & Phe & Ala & $71^{\mathrm{c}}$ \\
\hline 18 & Phe & Phe & $90^{c}$ \\
\hline 19 & Phe & Val & $73^{c}$ \\
\hline 20 & Val & Val & $91^{\circ}$ \\
\hline
\end{tabular}

Yields for the oxidative coupling of Ac-AA ${ }^{1}-\mathrm{SH}(50 \mathrm{mM})$ and $\mathrm{AA}^{2}-\mathrm{CN}(100 \mathrm{mM})$ with $\mathrm{K}_{3}\left[\mathrm{Fe}(\mathrm{CN})_{6}\right](150$ $\mathrm{mM}$ ) in water at room temperature and $\mathrm{pH} 9.0 .{ }^{1} \mathrm{H}$ NMR yields determined with an internal NMR standard, unless stated otherwise.

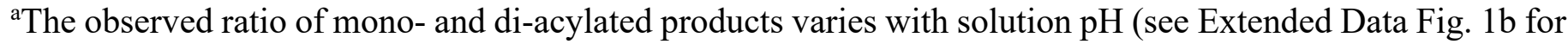
$\alpha$-selectivity of Lys-CN ligation at $\mathrm{pH} 7.5$, and Supplementary Table 13).

${ }^{b}$ Yield for the coupling of Ac-Lys-SH $(32 \mathrm{mM})$ with Gly-CN $(64 \mathrm{mM})$ and $\mathrm{K}_{3}\left[\mathrm{Fe}(\mathrm{CN})_{6}\right](96 \mathrm{mM})$.

${ }^{c}$ Isolated yield. 
a<smiles>CC(=O)NCC(=O)NC(CS)C(=O)O</smiles>

b<smiles>[X]C(N)C(=O)NCC(=O)NCC(=O)NCC(=O)NC([Y])C([Y])NN</smiles>

Lys-X Ac-Gly- $\alpha$-Lys-X Ac-Gly- - -Lys-X

$\mathrm{X}=\mathrm{CO}_{2} \mathrm{H} \quad \alpha / \varepsilon=1 \cdot 2: 1$

$\begin{array}{ll}\mathrm{X}=\mathrm{CONH}_{2} & \alpha / \varepsilon=2.7: 1 \\ \mathrm{X}=\mathrm{CN} & \alpha / \varepsilon>80: 1\end{array}$

c

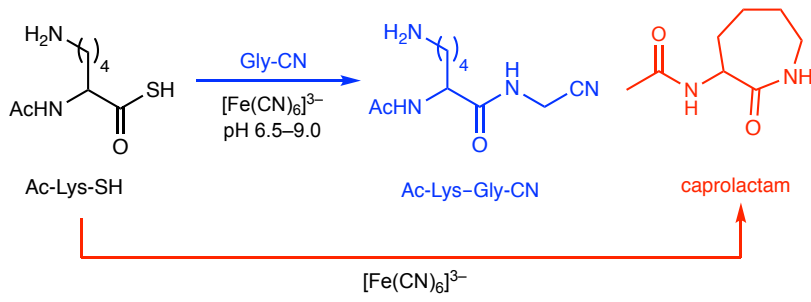

Extended Data Figure 1 | Chemoselective native peptide bond ligations of cysteine and lysine residues.

a. Ligation of Cys is notoriously challenging due to its highly nucleophilic thiol side chain, which necessitates $S$-protection to prevent it outcompeting $C$ and/or $N$-terminal activation through degradation of the electrophilic activating agents. Protecting-group-free ligation of Cys $(150 \mathrm{mM})$ is achieved through reaction with Ac-Gly$\mathrm{SH}(50 \mathrm{mM})$ and $\mathrm{K}_{3}\left[\mathrm{Fe}(\mathrm{CN})_{6}\right](300 \mathrm{mM})$ in water $(\mathrm{pH} 9.5$, room temperature), followed by thiol reduction (MeSH, $600 \mathrm{mM}, \mathrm{pH}$ 10.8, room temperature) to give Ac-Gly-Cys-OH in high yield (80\%, over two steps) (Supplementary Figures 112-114). b. Lys-X coupling partners $\left(\mathrm{X}=\mathrm{CN}, \mathrm{CONH}_{2}\right.$ or $\left.\mathrm{CO}_{2} \mathrm{H}\right)$ pose greater chemoselectivity challenges because they possess two amino groups $\left(\alpha-\mathrm{NH}_{2}\right.$ and $\left.\varepsilon-\mathrm{NH}_{2}\right)$. However, $\mathrm{p} K_{\mathrm{a}^{-}}$ controlled native peptide ligation of Lys-CN demonstrates the pivotal role that the unusually low $\alpha$-amine $\mathrm{p} K_{\mathrm{aH}}$ of $\alpha$-aminonitriles ${ }^{19}$ can play in selective ligation. Ligation of Lys-CN (100 mM) with Ac-Gly-SH (50 $\mathrm{mM}$ ) proceeds with unprecedented selectivity in neutral water ( $\mathrm{pH} 7.5$, room temperature). Little or no selectivity was observed for the corresponding $\alpha$-amino amide (Lys- $\mathrm{NH}_{2} ; 150 \mathrm{mM}$ ) and $\alpha$-amino acid (Lys; $150 \mathrm{mM}$ ) (Supplementary Figure 145-151). c. Selective intermolecular ligation of the $C$-terminal lysine residue with $\alpha$-aminonitrile coupling partner Gly-CN at near-neutral $\mathrm{pH}$ ( $\mathrm{pH} 6.5$ - 9.0 (blue); see Supplementary Figure 70). In the absence of Gly-CN highly efficient intramolecular caprolactam formation is observed (red). 